Hubungan Panjang dan Bobot, ..... Tertangkap di Samudera Hindia (Faizah, R. \& B.I. Prisantoso)

\title{
HUBUNGAN PANJANG DAN BOBOT, SEBARAN FREKUENSI PANJANG, DAN FAKTOR KONDISI TUNA MATA BESAR (Thunnus obesus) YANG TERTANGKAP DI SAMUDERA HINDIA
}

\author{
Ria Faizah dan Budi Iskandar Prisantoso \\ Peneliti pada Pusat Penelitian Pengelolaan Perikanan dan Konservasi Sumber Daya Ikan, Ancol-Jakarta \\ Teregistrasi I tanggal: 24 September 2010; Diterima setelah perbaikan tanggal: 19 Nopember 2010; \\ Disetujui terbit tanggal: 30 Nopember 2010
}

\begin{abstract}
ABSTRAK
Penelitian ini tentang hubungan panjang dan bobot, distribusi frekuensi panjang dan faktor kondisi ikan tuna mata besar (Thunnus obesus) di Samudera Hindia dilakukan pada bulan Maret sampai Oktober 2008. Hasil penelitian ini menunjukan tangkapan rawai tuna di perairan sebelah selatan Jawa Timur sampai Nusa Tenggara diperoleh ukuran tuna mata besar berkisar antara $98-153 \mathrm{~cm}$ (rata-rata 127,07 kg) dan bobot antara $20-73 \mathrm{~kg}$ (rata-rata 41,44 kg). Hubungan panjang dan bobot mengikuti persamaan $\mathrm{W}=0,023 \mathrm{FL}^{2,9652}$. Nilai faktor kondisi tuna mata besar berkisar antara 1,852,12 dan menunjukan nilai faktor kondisi ini berfluktuasi setiap bulan.
\end{abstract}

KATAKUNCl: hubungan panjang dan bobot, distribusi frekuensi panjang, faktor kondisi, tuna mata besar, Samudera Hindia

ABSTRACT: $\quad$ Length and weight relationship, length frequency distribution, and condition factors of big eye tuna (Thunnus obesus) caugth in the Indian Ocean. By: Ria Faizah and Budi Iskandar Prisantoso

Study on length and weight relationship, length frequency distribution and condition factors of big eye tuna (Thunnus obesus) in the Indian Ocean was conducted in March to October 2008. The results showed that size of big eye tuna that caught by tuna long line from the southest of Java Sea and Nusa Tenggara were ranging from $98-153 \mathrm{~cm}$ in fork length (average of $127.07 \mathrm{~kg}$ ); and weight range of 20$73 \mathrm{~kg}$ (average of 41,44 kg). Length and weight relationship of big eye tuna can be described as $W=0,023 F^{2,9652}$. Condition factor of big eye tuna were ranging from 1.85-2.12 and that fluctuated monthly.

KEYWORDS: $\quad$ length and weight relationship, length frequency distribution, condition factors, big eye tuna, Indian Ocean

\section{PENDAHULUAN}

Analisis hubungan panjang dan bobot merupakan aspek penting dalam mempelajari biologi ikan, fisiologi, ekologi, dan merupakan dasar yang digunakan untuk mengetahui informasi tentang faktor kondisi ikan serta mendeterminasi sifat pertumbuhan ikan apakah isometrik atau alometrik (Ricker 1975; Oscoz et al., 2005). Hubungan panjang dan bobot juga dapat digunakan untuk mendeterminasi bobot dan biomassa jika hanya ukuran panjang yang diperoleh sebagai indikasi perbandingan parameter pertumbuhan dari daerah yang berbeda. Menurut Merta (1993) analisis hubungan panjang dan bobot dimaksudkan untuk mengukur variasi bobot harapan untuk panjang tertentu dari ikan secara individual atau kelompok-kelompok individu sebagai suatu petunjuk tentang kegemukan, kesehatan, perkembangan gonad, dan sebagainya. Everhart \& Youngs (1981), mengatakan kegunaan lain dari analisis hubungan panjang dan bobot yaitu dapat digunakan untuk melakukan estimasi faktor kondisi atau sering disebut dengan index of plumpness, yang merupakan salah satu derivat penting dari pertumbuhan untuk membandingkan kondisi atau keadaan kesehatan relatif populasi ikan atau individu tertentu.

Tuna mata besar (Thunnus obesus Lowe, 1839) merupakan salah satu spesies tuna komersial penting yang hidup di perairan hangat di Samudera Atlantik, Samudera Hindia, dan Samudera Pasifik. Menurut Joseph (2003), saat ini status stok tuna mata besar hampir di ambang kelebihan tangkap (over fishing). Terkait hal tersebut maka data biologi sangat diperlukan sebagai bahan masukan bagi pengelola perikanan. Hasil penelitian ini didasarkan atas data yang dikumpulkan dari kapal rawai tuna yang beroperasi di Samudera Hindia berbasis di Benoa, Bali. 


\section{BAHAN DAN METODE}

\section{Lokasi dan Waktu Penelitian}

Penelitian ini dilakukan di perairan Samudera Hindia pada bulan Maret sampai Oktober 2008. Pengukuran panjang dan bobot individu serta pengambilan contoh gonad ikan tuna mata besar dilakukan oleh observer dengan mengikuti kapal rawai tuna yang berbasis di Benoa. Lokasi daerah penangkapan ikan berada di perairan Samudera Hindia sebelah selatan Jawa Timur, Bali sampai Nusa Tenggara pada posisi geografis antara $09^{\circ} 11^{\prime}-16^{\circ} 07^{\prime}$ LS dan 110 15'-118 35' BT (Gambar 1).

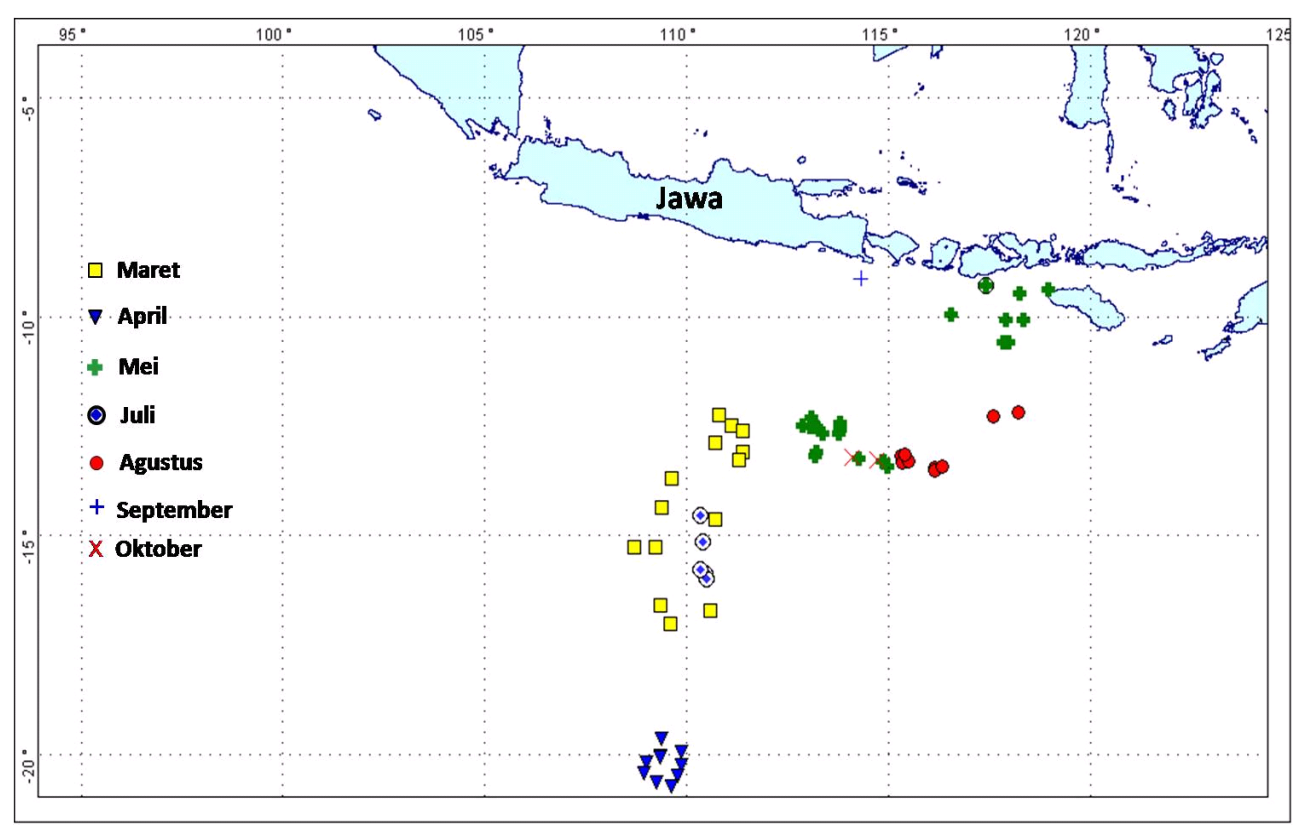

Gambar 1. Peta lokasi pengambilan contoh.

Figure 1. Map of sampling positions.

\section{Hubungan Panjang dan Bobot}

Hubungan panjang dan bobot ikan dianalisis dengan model persamaan Hile (1936) dalam Effendie (2002) sebagai berikut:

$$
\mathrm{W}=\mathrm{aL}^{\mathrm{b}}
$$

di mana:

$$
\begin{array}{ll}
\mathrm{W} & =\text { bobot ikan }(\mathrm{kg}) \\
\mathrm{L} & =\text { panjang ikan }(\mathrm{cm}) \\
\mathrm{a} \text { dan } \mathrm{b} & =\text { konstanta }
\end{array}
$$

Dari persamaan tersebut dapat diketahui pola pertumbuhan panjang dan bobot ikan. Nilai b yang diperoleh digunakan untuk menentukan pola pertumbuhan dengan kriteria:

1. Jika $b=3$, pertumbuhan bersifat isometrik, yaitu pertumbuhan panjang sama dengan pertumbuhan bobot.

2. Jika $b>3$ maka pola pertumbuhan bersifat allometrik positif, yaitu pertambahan bobot lebih cepat dari pertambahan panjang.
3. Jika $b<3$ maka pola pertumbuhan bersifat allometrik negatif, yaitu pertambahan panjang lebih cepat dari pertambahan bobot.

Kesimpulan dari nilai b yang diperoleh ditentukan dengan menggunakan uji-t pada selang kepercayaan $95 \%(\alpha=0,05)$ (Steell \& Torrie 1989).

\section{Faktor Kondisi}

Faktor kondisi ikan dikatakan dalam angka yang dihitung sesuai dengan persamaan yang dikatakan Goddard (1996):

$$
\mathrm{Kt}=10^{2} \mathrm{~W} / \mathrm{L}^{3}
$$

dimana:

$$
\begin{aligned}
& \mathrm{Kt}=\text { faktor kondisi } \\
& \mathrm{W}=\text { bobot rata-rata ikan }(\mathrm{g}) \\
& \mathrm{L}=\text { panjang rata-rata ikan }(\mathrm{cm})
\end{aligned}
$$




\section{HASIL DAN BAHASAN}

\section{Hubungan Panjang dan Bobot}

Pengukuran individu terhadap 121 ekor ikan tuna mata besar yang tertangkap diperoleh kisaran panjang cagak antara $98-153 \mathrm{~cm}$ dengan kisaran bobot antara 19-73 kg. Analisis hubungan panjang dan bobot diperoleh persamaan sebagai berikut $\mathrm{W}=0,023^{*}$ $\mathrm{FL}^{2,9652}$ dengan nilai koefisien korelasi $(=r) 0,9554$. Nilai ini menunjukan bahwa korelasi antara panjang dan bobot ikan sangat signifikan (Gambar 2). Besar keeratan hubungannya ditentukan oleh masingmasing koefisien determinasinya $\left(r^{2}\right)$, yaitu 0,9066 . Diperoleh nilai b (slope) 2,9652. Menurut Effendie (2002) bila nilai b berada diluar kisaran antara 2,43,5 , maka bentuk tubuh ikan di luar batas kebiasaan bentuk ikan secara umum. Berdasarkan atas hasil uji-t terhadap parameter b pada selang kepercayaan $95 \%(a=0,05)$, diperoleh $t_{\text {hit }}>t_{\text {tab }}$ ( $b$ “'3) yang artinya pola pertumbuhan ikan tuna mata besar cenderung bersifat allometrik negatif yaitu pertumbuhan bobot tidak secepat pertumbuhan panjangnya.

Pertumbuhan dipengaruhi oleh faktor luar dan faktor dalam. Faktor luar sulit dikontrol yang meliputi keturunan, sex, umur, parasit, dan penyakit. Faktor luar utama yang mempengaruhi pertumbuhan adalah makanan dan suhu perairan (Effendie, 2002). Hubungan panjang dan bobot tuna mata besar di Samudera Hindia memiliki pola yang sama dengan hasil penelitian di Samudera Pasifik bagian barat. Hasil penelitian Sun et al. (2001) mengatakan ikan tuna mata besar di perairan Samudera Pasifik bagian barat dari tangkapan rawai tuna juga bersifat allometrik negatif dengan persamaan $\mathrm{W}=3 \times 10{ }^{-5} \mathrm{FL}^{2,9278}\left(\mathrm{r}^{2}=0,97\right.$, $\mathrm{n}=856$ ). Hubungan panjang dan bobot tuna mata besar dalam penelitian ini juga mirip dengan yang dikatakan oleh Zhu et al. (2008) yang melakukan penelitian tuna mata besar di Samudera Hindia, di mana hasil tangkapan rawai tuna bersifat allometrik negatif dengan persamaan $\mathrm{W}=0,00002601 \mathrm{FL}^{2,9362}\left(\mathrm{r}^{2}=0,9567\right.$, $n=741)$.

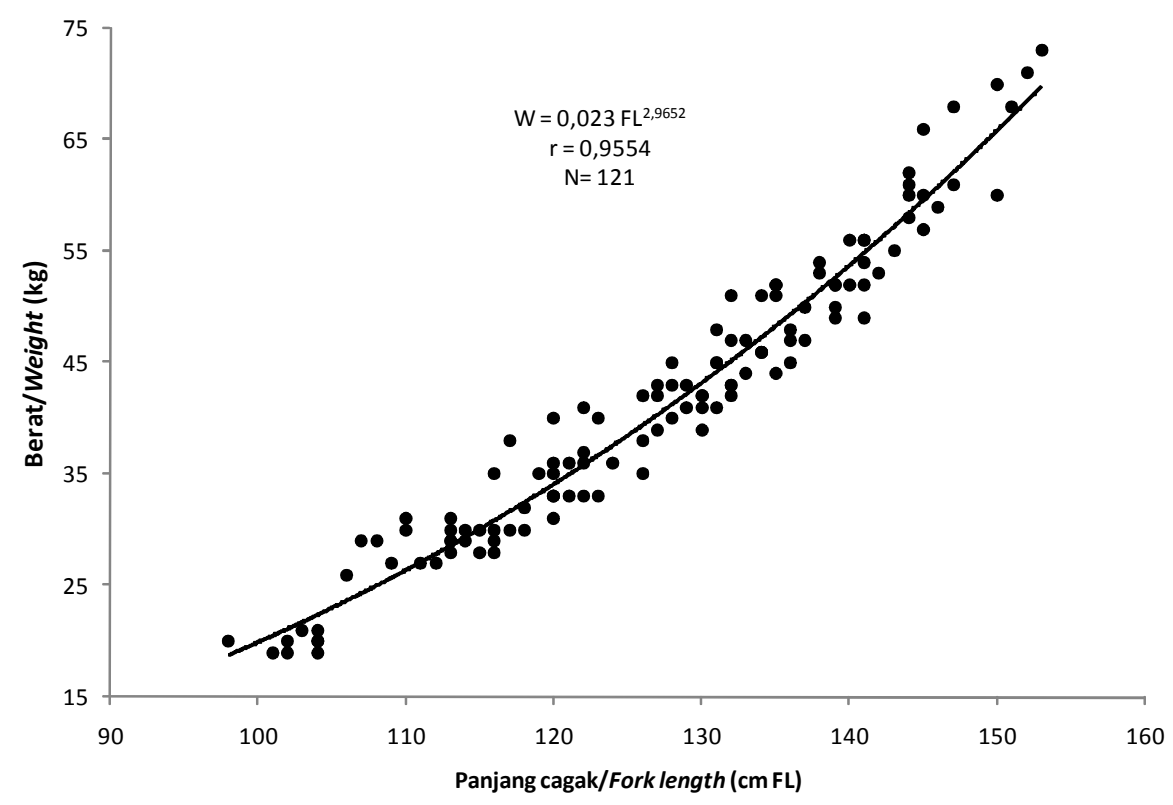

Gambar 2. Hubungan panjang dan bobot ikan tuna mata besar di Samudera Hindia (bulan Maret sampai Oktober 2008).

Figure 2. Length and weigth relationship of big eye tuna in the Indian Ocean, March until October 2008.

\section{Sebaran Frekuensi Panjang Ikan Tuna Mata Besar}

Posisi geografis pengambilan contoh ikan tuna mata besar diduga juga merupakan daerah penangkapan ikan tuna mata besar. Dari gambar tersebut terlihat bahwa lokasi pengambilan contoh setiap bulannya berbeda kecuali pada bulan Mei dan Oktober. Pengambilan contoh yang dilakukan dari bulan Maret sampai Oktober 2008 diperoleh 121 ekor ikan tuna mata besar. Hasil pengamatan menunjukan pada bulan Maret ukuran menyebar pada kisaran 112- 
$147 \mathrm{~cm}$ dengan panjang cagak rata-rata 130,64 cm, pada bulan April memiliki panjang cagak rata-rata $132,47 \mathrm{~cm}$ dan menyebar pada selang ukuran antara $114-153 \mathrm{~cm}$. Pada bulan Mei ikan yang paling banyak tertangkap berkisar antara 130-137 cm (25,87\%), bulan Juli ikan yang tertangkap memiliki ukuran panjang 104-138 cm dengan panjang rata-rata 120,5 $\mathrm{cm}$, pada bulan Agustus ikan yang tertangkap memiliki ukuran 98-105 cm dan pada bulan September ikan yang tertangkap memiliki ukuran $132 \mathrm{~cm}$ dan bulan Oktober ikan yang tertangkap memiliki panjang cagak rata-rata $138,5 \mathrm{~cm}$ (Tabel 1 ).

Tabel 1. Ukuran panjang ikan tuna mata besar menurut waktu penelitian di Samudera Hindia Table 1. Length of big eye tuna based on research duration in the Indian Ocean

\begin{tabular}{|c|c|c|c|c|c|}
\hline \multirow{2}{*}{$\begin{array}{l}\text { Bulan/ } \\
\text { Month }\end{array}$} & \multicolumn{2}{|c|}{$\begin{array}{l}\text { Kisaran posisi geografis/ } \\
\text { The range of geographical position }\end{array}$} & \multirow{2}{*}{$\begin{array}{l}\text { Jumlah } \\
\text { contoh/ } \\
\text { Total } \\
\text { sample } \\
\text { (n) }\end{array}$} & \multirow{2}{*}{$\begin{array}{c}\text { Selang } \\
\text { panjang/ } \\
\text { Hose length } \\
\text { (cm) }\end{array}$} & \multirow{2}{*}{$\begin{array}{c}\text { Panjang } \\
\text { rata-rata/ } \\
\text { The average } \\
\text { length (cm } \\
\text { FL) }\end{array}$} \\
\hline & Bujur/ & Lintang/Latitude & & & \\
\hline Maret 2008 & $108^{\circ} 41^{\prime}-111^{\circ} 28^{\prime} \mathrm{BT}$ & $12^{\circ} 15^{\prime}-16^{\circ} 07^{\prime}$ LS & 14 & $112-147$ & 130,6 \\
\hline April 2008 & $108^{\circ} 57^{\prime}-109^{\circ} 51^{\prime} \mathrm{BT}$ & $19^{\circ} 38^{\prime}-20^{\circ} 42^{\prime}$ LS & 19 & $114-153$ & 132,4 \\
\hline Mei 2008 & $112^{\circ} 52^{\prime}-118^{\circ} 57^{\prime}$ BT & $9^{\circ} 13^{\prime}-13^{\circ} 25^{\prime}$ LS & 58 & $101-152$ & 128,7 \\
\hline Juli 2008 & $110^{\circ} 19^{\prime}-117^{\circ} 23^{\prime}$ BT & $9^{\circ} 18^{\prime}-15^{\circ} 59^{\prime}$ LS & 7 & $104-138$ & 120,5 \\
\hline Agustus 2008 & $115^{\circ} 17^{\prime}-117^{\circ} 11^{\prime} \mathrm{BT}$ & $12^{\circ} 11^{\prime}-15^{\circ} 31^{\prime}$ LS & 20 & $98-140$ & 115,3 \\
\hline September 2008 & $114^{\circ} 19^{\prime} \mathrm{BT}$ & $9^{\circ} 8^{\prime} \mathrm{LS}$ & 1 & 132 & 132 \\
\hline Oktober 2008 & $114^{\circ} 06^{\prime}-114^{\circ} 43^{\prime} \mathrm{BT}$ & $13^{\circ} 13^{\prime}-13^{\circ} 16^{\prime} \mathrm{LS}$ & 2 & $136-141$ & 138,5 \\
\hline
\end{tabular}

Berdasarkan atas lokasi dan waktu pengambilan contoh ikan tuna mata besar sebagaimana pada Tabel 1 diperoleh ukuran yang relatif sama pada setiap lokasi dan waktu pengambilan contoh. Diduga bahwa ikan tuna mata besar pada lokasi tersebut satu umur dan memiliki tahap pertumbuhan yang relatif sama.

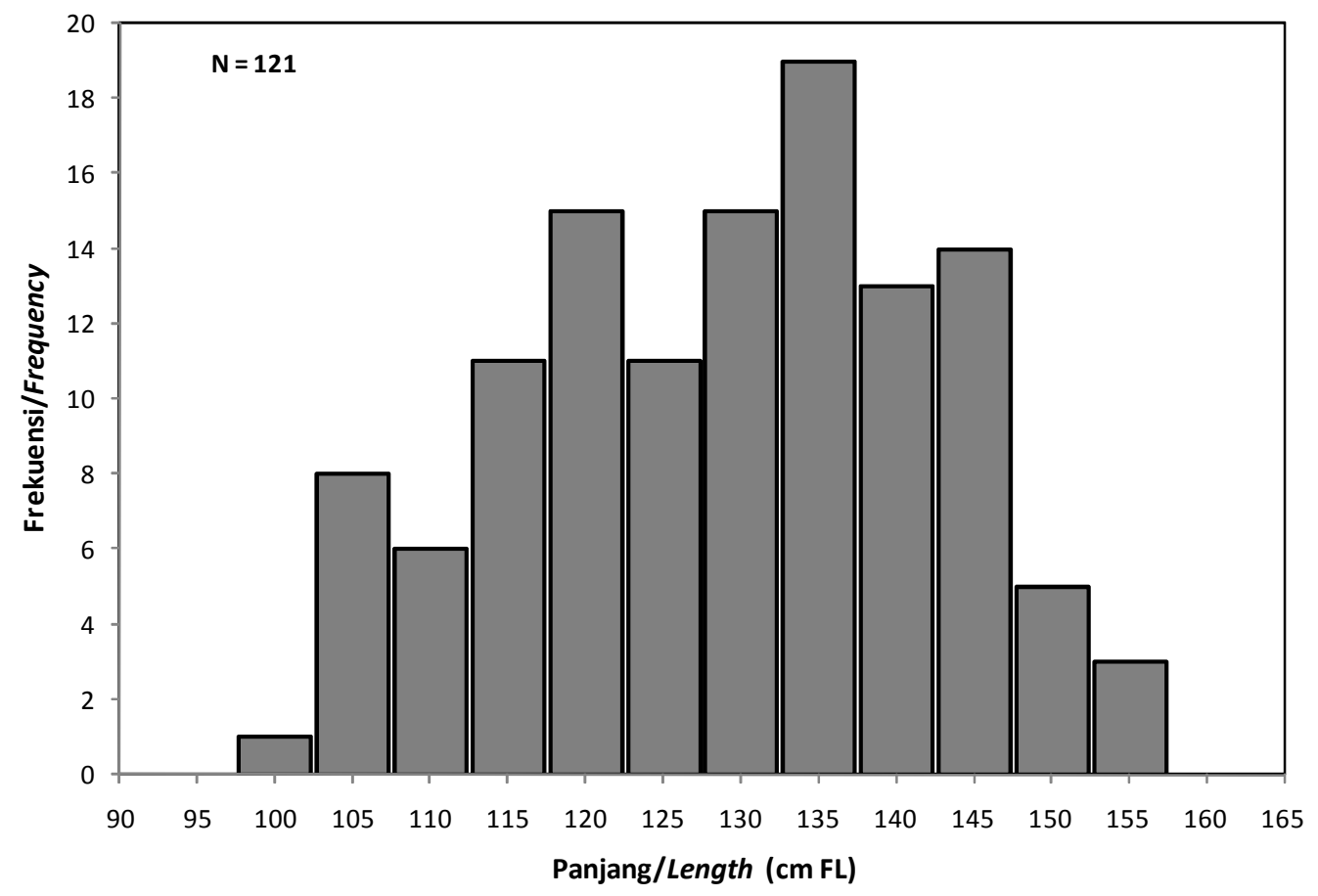

Gambar 3. Sebaran frekuensi panjang ikan tuna mata besar yang tertangkap di perairan Samudera Hindia bulan Maret sampai Oktober 2008.

Figure 3. Length frequency distribution of big eye tuna caught in the Indian Ocean, March until October 2008. 
Sebaran frekuensi panjang ikan tuna mata besar yang tertangkap pada bulan Maret sampai Oktober 2008 terdapat pada selang ukuran panjang cagak antara 98-153 cm FL (rata-rata 127,1 cm); dengan kisaran bobot antara $20-73 \mathrm{~kg}$ (rata-rata $41,4 \mathrm{~kg}$ ) (Gambar 3). Ikan yang paling banyak tertangkap berkisar pada selang kelas panjang cagak 132-139 $\mathrm{cm}$. Ukuran ikan tersebut mirip dengan hasil penelitian ikan tuna mata besar dari Samudera Hindia yang tercatat di Phuket, Tahiland yaitu berkisar antara 85$155 \mathrm{~cm}$ (Nootmorn, 2004). Ukuran ikan tuna mata besar dari Samudera Hindia bagian barat yang didaratkan di Seychelles berkisar antara110-150 FL cm (Indian Ocean Tuna Commission, 2005).

\section{Faktor Kondisi}

Faktor kondisi merupakan derivat dari pertumbuhan dan sering disebut sebagai faktor $\mathrm{K}$. Faktor kondisi ini menunjukan keadaan baik dari ikan dilihat dari kapasitas fisik dan reproduksi (Effendie, 2002). Hubungan antara faktor kondisi dengan ukuran ikan tuna mata besar di Samudera Hindia disajikan pada Gambar 4. Dari Gambar tersebut tampak bahwa nilai faktor kondisi tertinggi $(=2,12)$ terdapat pada selang panjang antara $106-113 \mathrm{~cm}$ FL dan terendah $(=1,85)$ terdapat pada selang panjang antara $98-105$ $\mathrm{cm} \mathrm{FL}$.

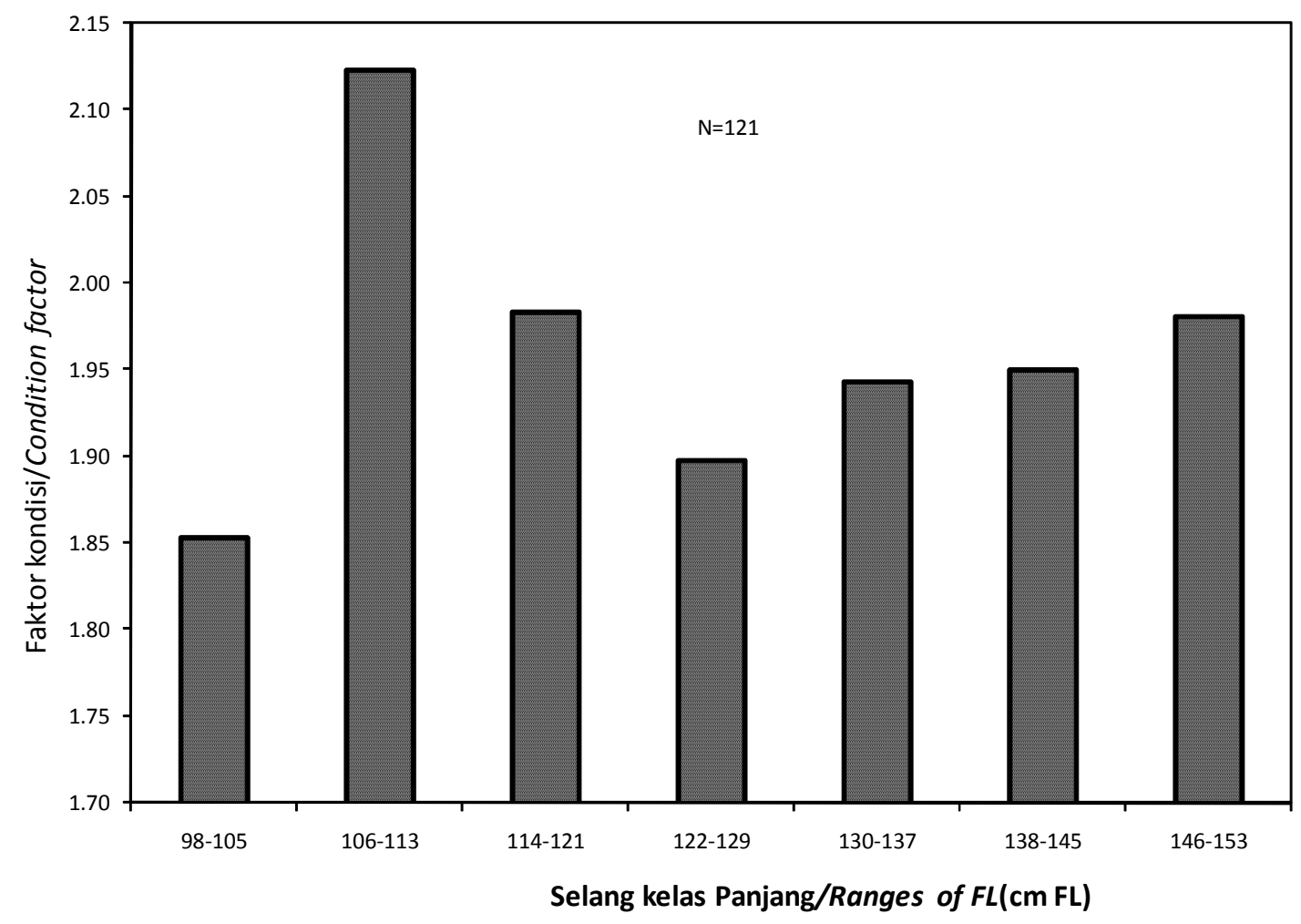

Gambar 4. Faktor kondisi dan frekuensi panjang ikan tuna mata besar di Samudera Hindia, bulan Maret sampai Oktober 2008.

Figure 4. Condition factor and length frequency of big eye tuna in the Indian Ocean, March until October 2008.

Fluktuasi nilai faktor kondisi ikan tuna mata besar juga ditentukan oleh waktu pengambilan contoh ikan. Nilai faktor kondisi pada bulan Maret 2008 adalah 1,99 , kemudian meningkat pada bulan April menjadi
2,01 dan diikuti penurunan menjadi 1,94 pada bulan berikutnya. Sejak bulan Mei sampai Oktober nilai faktor kondisi meningkat terus dan nilai tertinggi $(=2,03)$ dicapai pada bulan Oktober Gambar 5 . 


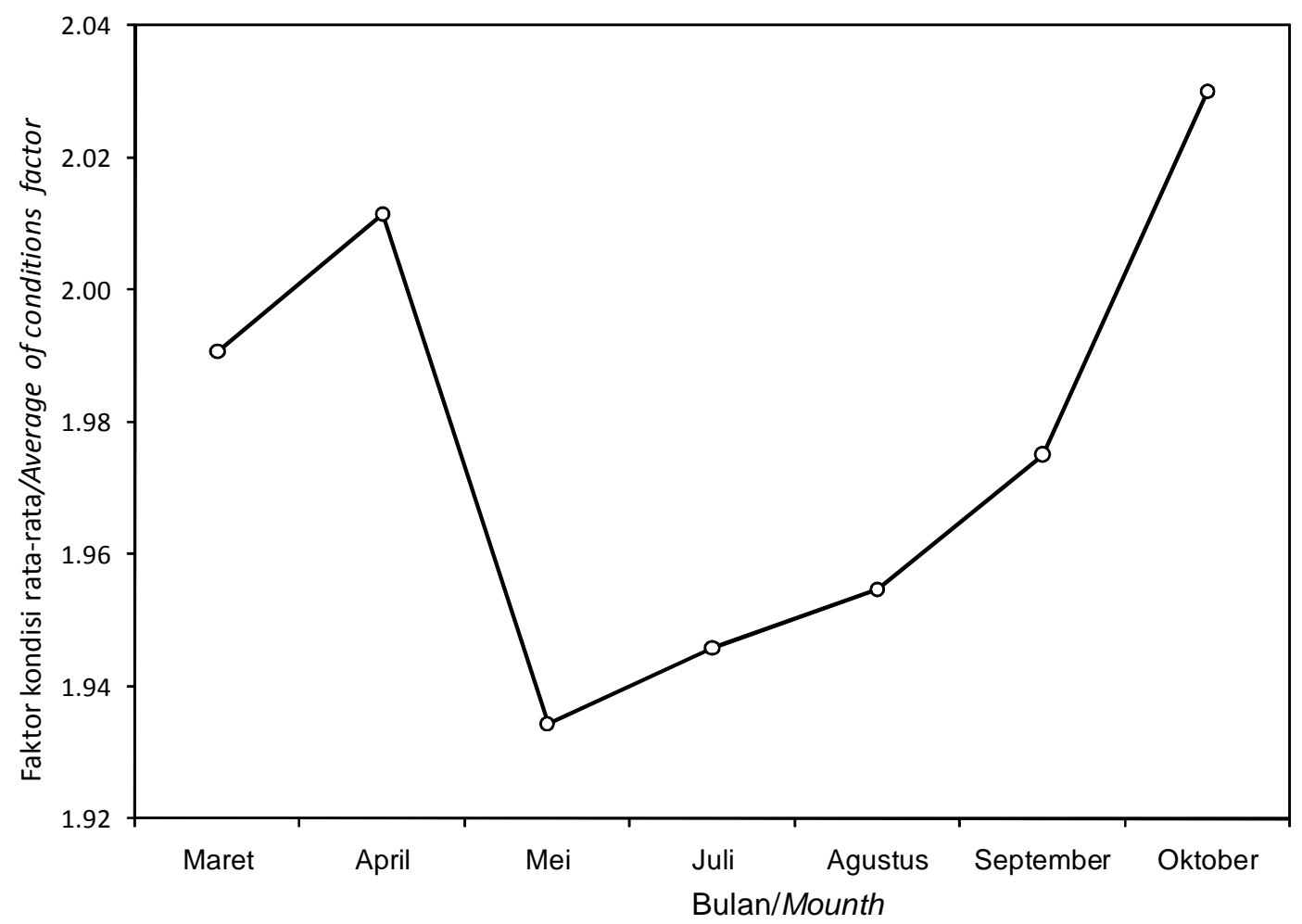

Gambar 5. Perubahan bulanan faktor kondisi ikan tuna mata besar di Samudera Hindia, bulan Maret

Figure 5. Monthly changes in condition factor of big eye tuna in the Indian Ocean, March until October 2008.

Kisaran nilai faktor kondisi pada penelitian ini tidak berbeda jauh dengan hasil penelitian di perairan Taiwan, yaitu berkisar antara 1,4-2,5 dan menunjukan adanya fluktuasi dari setiap ukuran dan tiap bulannya (Wang et al., 2002).

Berdasarkan atas gambar tersebut, nilai faktor kondisi rata-rata ikan tuna mata besar berfluktuasi pada setiap selang ukuran dan bulan. Hal ini kemungkinan disebabkan oleh perbedaan umur, tingkat kematangan gonad, kondisi lingkungan, dan ketersediaan makanan di perairan tersebut. Menurut Effendie (2002) bahwa variasi nilai faktor kondisi tergantung kepada kepadatan populasi, tingkat kematangan gonad, makanan, jenis kelamin, dan umurikan.

\section{KESIMPULAN}

1. Hubungan panjang dan bobot ikan tuna mata besar di Samudera Hindia mengikuti persamaan $\mathrm{W}=0,023^{\star} \mathrm{FL}^{2,9652}$. Pola pertumbuhan tersebut bersifat allometrik negatif.

2. Ikan tuna mata besar yang tertangkap dengan rawai tuna pada bulan Maret sampai Oktober 2008 di Samudera Hindia memiliki ukuran yang relatif seragam pada kisaran antara $98-153 \mathrm{~cm}$ FL.

3. Faktor kondisi ikan tuna mata besar berfluktuasi pada setiap ukuran dan bulan.

\section{PERSANTUNAN}

Tulisan ini merupakan kontribusi dari kegiatan hasil riset studi populasi genetik dengan menggunakan marker DNA dan biologi reproduktif ikan tuna Samudera Hindia, T. A. 2008, di Pusat Riset Perikanan Tangkap-Ancol, Jakarta. Penulis mengucapkan terima kasih kepada PT. Samodera Besar dan para observer pada Stasiun Monitoring Tuna Benoa, Pusat Riset Perikanan Tangkap yang telah membantu dalam pengumpulan data pada kapal rawai tuna di Samudera Hindia sebelah selatan Jawa, Bali, dan Nusa Tenggara.

\section{DAFTAR PUSTAKA}

Effendie, I. M. 2002. Biologi Perikanan. Yayasan Pustaka Nusantara. Bogor. 
Everhart, W. H. \& W. D. Youngs. 1981. Principles of Fishery Science. $2^{\text {nd }}$ Edition. Comstock Publishing Associates, a Division of Cornell University Press. Ithaca and London. $349 \mathrm{pp}$.

Goddard, S. 1996. Feed Management in Intensive Aquaqulture. Fisheries and Marine Institute Memorial University. Newfounland. Canada. Chapman and Hall. New York.

Indian Ocean Tuna Commission. 2005. Report of the Eight Session of the Scientific Committee. Indian Ocean Tuna Commission-2005-SC-R[EN]. Indian Ocean Tuna Commission, Victoria, Seychelles. http://www.iotc.org/English/index.php. Diunduh Tanggal 26 Agustus 2009.

Lowe, R. T. 1839. A supplement to a synopsis of the fishes of Madeira. Proc. Zool. Sic. Lond. 76-92.

Joseph, J. 2003. Managing Fishing Capacity of the World Tuna Fleet. FAO Fisheries Circular No.982.

Merta, I. G. S. 1993. Hubungan panjang dan bobot dan faktor kondisi ikan lemuru, Sardinella lemuru Bleeker, 1853 dari perairan Selat Bali. Jurnal Penelitian Perikanan Laut. 73: 35-44.

Nootmorn, P. 2004. Reproductive biology of big eye tuna in the eastern Indian ocean. Indian Ocean Tuna Commission Proceedings. 7:1-5.

Oscoz, J., F. Campos, \& M. C. Escala. 2005. Weight and length relationships of some fish species of the Iberian Peninsula. Journal of Applied Ichthyology. 21: 73-74.

Ricker, W. E. 1975. Computation and interpretation of biological statistics of fish populations. Fish. Res. Bd. Can. Bull. 191: 382 pp.

Steell, R. G. H \& J. H. Torrie. 1989. Prinsip dan Prosedur Statistika: Suatu Pendekatan Biometrik (Terjemahan dari Principle and Procedure of Statistic: A Biometri Approach). Sumantri, B. (penerjemah). Edisi kedua. PT. Gramedia. Jakarta. $748 \mathrm{pp}$.

Sun, C. L, C. L. Huang. \& S. Z Yeh. 2001. Age and growth of the big eye tuna Thunnus obesus in the western Pacific Ocean. Fish. Bull. 99: 502-509.

Wang, S. B., F. C. Chang, S. H. Wang, \& C. L. Kuo. 2002. Some biological parameters of big eye and yellowfin tunas distributed in surrounding waters of Taiwan. $15^{\text {th }}$ meeting of the Standing Committee on Tuna and Billfish. Hawaii, July 22-27, 2002. SCTB15 Working Paper. 13 pp.

Zhu, G., L. Xu, Y. Zhou, \& X. Dai. 2008. Length frequency compositions and weight and length relations for big eye tuna, yellowfin tuna, and albacore (Perciformes: Scombrinae) in the Atlantic, Indian, and Eastern Pacific Oceans. Acat Ichthiologica Et Piscatoria. 38 (2): 157-161. 